\title{
ВПЛИВ ЛЕГАЛІЗАЦІї (ВІДМИВАННЯ) ДОХОДІВ, ОДЕРЖАНИХ ЗЛОЧИННИМ ШЛЯХОМ, НА ЕКОНОМІЧНУ СФЕРУ УКРАЇНИ В СУЧАСНИХ УMOBAX
}

\author{
ГОНЧАРУК Владислав Леонідович - старший науковий співробітник \\ наукової лабораторії № 1 науково-організаційного центру Національної академії \\ Служби безпеки України \\ orcid.org/0000-0002-9627-9530 \\ DOI 10.32782/LAW.UA.2021.4.18
}

В статье исследовано влияние легализаичии (отмъгвания) доходов, полученнъих преступнъим путем, на экономическую сберу Украинъ в современньх условиях. В ходе исследования установлено, что надлежащее обеспечение начиональньх якономических интересов требует формирования и реализачии стратегического курса в сфере экономической безопасности. Автором обращается внимание на то, ито противодействие легализации (отмъиванию) доходов, полученнъхх преступнъим путем, требует осознания природъ и фбакторов распространения этого общественноопасного явления, а также соответствующего правового обеспечения, согласованного с международнъми стандартами и практиками.

Отмечено, что обеспечение экономической системь на всех уровнях управления является важной задачей для подавляющего большинства стран мира, поскольку решить экономические проблемъ целого государства или региона невозможно без надлежащего обеспечения экономической безопасности и стабильного развития.

В работе отмечено, что сегодня легализачия (отмьгвание) доходов, полученньгх преступнъим путем, является одним из самъх прибъльнъгх видов незаконного предпринимательства во всем мире. В ходе исследования приводятся даннъие Государственной службъ фбинансового мониторинга Украинъ (как подразделения фбнансовой разведки) в части осуществления мер по противодействию ле- гализащии (отмыванию) доходов, полученнъгх преступнъм путем, бинансированию терроризма, сепаратизма, а также въцеляются наиболее распространеннъе источники происхождения доходов, полученных преступным путем.

Ключевъе слова: легализачия (отмъввание) доходов, полученнъх преступнъм путем; экономическая сфера; бинансовая безопасность; Финансовая система; национальная безопасность; высоколиквиднъе активъ.

Постановка проблеми

Економічна безпека країни може бути досягнута лише за умови ефективного правового та державного регулювання. Моніторинг та прогнозування факторів, що підривають стійкість національної економіки, виявлення можливих загроз економічній безпеці та вироблення заходів щодо їх запобігання є першочерговим завданням будьякої держави.

Стратегією економічної безпеки України на період до 2025 року [12] визначено шляхи досягнення цілей і реалізації пріоритетів національних інтересів у сфері забезпечення економічної безпеки.

Державним інтересам України відповідає сталий розвиток національної економіки, інтеграція України в європейський економічний простір, розвиток рівноправного взаємовигідного економічного співробітництва з іншими державами. 
Забезпечення національних економічних інтересів вимагає формування і реалізації стратегічного курсу у сфері забезпечення економічної безпеки, спрямованого як на стале нарощення конкурентоспроможності економіки України, так і на поступове зміцнення економічної стійкості та відповідно невразливості національної економіки до зовнішніх і внутрішніх загроз.

Поряд з цим, у зв'язку з активним розвитком економічної системи, технологічним удосконаленням здійснення фінансових операцій, проникненням у національну економіку транснаціональної злочинності, створюють систему загроз для фінансових ринків України, які здійснюються за допомогою вливання злочинних капіталів в економіку. Протидія легалізації (відмивання) доходів, одержаних злочинним шляхом, потребує усвідомлення природи та чинників поширення цього суспільно небезпечного явища, а також відповідного правового забезпечення, узгодженого 3 міжнародними стандартами та практиками [4, с. 180].

Таким чином, однією 3 основних наявних проблем у сфері забезпечення економічної безпеки України вимагає вироблення комплексного рішення, яке 6 стосувалося відповідної державної політики з протидії корупції та тіньової економіки.

\section{Аналіз останніх досліджень і публікацій}

У теорії кримінального права проблемам легалізації (відмивання) доходів, одержаного злочинним шляхом, приділяли увагу значна кількість науковців, серед яких: П. П. Андрушко, О. М. Бандурка, О. О. Дудоров, М. І. Мельник, В. О. Навроцький, В. А. Ортинський, О. Б. Полторацький, Т. М. Тертиченко, О. В. Халін та інші. Водночас, не зважаючи на значну кількість наукових праць у цій царині, потребують подальших наукових розвідок питання, які стосуються впливу легалізації (відмивання) доходів, одержаних злочинним шляхом, на економічну сферу України в сучасних умовах.

Метою статті $є$ дослідження взаємозв'язку між легалізацією (відмиванням) доходів, одержаних злочинним шля- хом, та її впливом на стабільність економічної сферу України.

\section{Виклад основного матеріалу}

Легалізація (відмивання) доходів, одержаного злочинним шляхом, сьогодні перетворилася у найприбутковіший вид незаконного підприємництва у всьому світі. Для надання допомоги щодо легалізації (відмивання) доходів залучаються висококваліфіковані фінансові аналітики, адвокати, аудитори та ін. Для визначення зазначених суспільно небезпечних діянь необхідно використовувати напрацювання міжнародних правових інституцій [4, с. 181].

Убезпечення економічної системи на всіх рівнях управління - це важливе завдання для переважної більшості країн світу, не винятком є і Україна. Адже вирішити економічні проблеми цілої держави, регіону чи то середньостатистичного підприємства просто неможливо без належного забезпечення їм економічної безпеки та стабільності. Таким чином, економічна безпека держави є головним критерієм, який визначає здатність окремої країни самостійно реалізовувати економічно-фінансову політику, що відповідає іï національним інтересам. У процесі здійснення цієї діяльності держава, в особі уповноважених органів, здійснює відповідні заходи, спрямовані на забезпечення стійкості розвитку держави проти: впливу на економічні процеси в державі світових фінансових криз; умисного впливу інших учасників загальносвітових економіко-фінансових відносин; впливу так званих «тіньових» структур на національну соціальну, політичну чи економічну систему, стрімкого розповсюдження суспільно небезпечних діянь у фінансовій сфері, зокрема, легалізації (відмиванню) доходів, одержаних злочинним шляхом; значного витоку капіталів за кордон та ін [11, c. 291].

Не зважаючи на складні суспільно-політичні умови в державі, уже тривалий період часу Україна продовжує вживати заходів щодо розвитку та вдосконалення системи проведення фінансових розслідувань відповідно до міжнародних стандартів [7, с. 37].

Сьогодні необхідно констатувати, що легалізація (відмивання) доходів, одержаних 


\section{Кримінальне право, кримінальний процес та криміналістика}

злочинним шляхом є одним 3 найприбутковіших видів незаконного підприємництва у всьому світі.

Про поширеність цього суспільно небезпечного діяння в Україні свідчать дані Державної служби фінансового моніторингу України. Так, лише за 9 місяців 2021 року Держфінмоніторингом, як підрозділом фінансової розвідки України, до правоохоронних органів було скеровано 933 матеріали щодо фінансових операцій, які можуть бути пов’ язані з легалізацією коштів, та із вчиненням кримінального правопорушення, становить 81,9 млрд гривень [5].

Також необхідно зазначити, що Держфінмоніторингом приділяється особлива увага і розслідуванню фактів легалізації (відмивання) коштів, одержаних від корупційних діянь, розкрадання та привласнення державних коштів та майна.

Так, протягом 9 місяців 2021 року Держфінмоніторингом направлено до правоохоронних органів 129 матеріалів. У вказаних матеріалах сума фінансових операцій, які можуть бути пов’язані з легалізацією коштів, та із вчиненням кримінального правопорушення, становить 7,9 млрд гривень.

У вказаних матеріалах сума фінансових операцій, які можуть бути пов'язані 3 легалізацією коштів та із вчиненням кримінального правопорушення, становить 7,9 млрд гривень.

Загальний обсяг «проконвертованих» коштів за цими матеріалами складає 16,5 млрд гривень.

Також необхідно відмітити, що в ході зазначених фінансових розслідувань Держфінмоніторингом зупинено (заблоковано) кошти у сумі 72,22 млн гривень.

Відповідно до законодавства України, Держфінмоніторинг (як підрозділ фінансової розвідки) спільно із правоохоронними органами здійснює заходи, направлені на попередження та протидію фінансуванню терористичної діяльності, сепаратизму.

Так, протягом 9 місяців 2021 року Держфінмоніторингом до правоохоронних органів передано 83 матеріали щодо фінансових операцій осіб, які, у тому числі за інформацією правоохоронних органів, можуть бути пов'язані 3 фінансуванням тероризму/сепа- ратизму; осіб, які публічно закликають до зміни чи повалення конституційного ладу або зміни меж території або державного кордону України, а також осіб, до яких застосовано санкції [5].

Як слушно зазначають О. М. Рєзнік та Н. М. Щербак, особливу соціальну небезпеку процесів легалізації доходів, одержаних злочинним шляхом, та їх безпосередню конфронтацію 3 головними цілями економічної та фінансової безпеки можна пояснити шляхом виокремлення двох основних аспектів. По-перше, такого роду суспільно небезпечні діяння відволікають на себе фінансові ресурси, передбачені на суспільний розвиток тих чи інших інститутів, призводячи до їх економічної стагнації та деградації. По-друге, легалізація (відмивання) доходів протиправного походження сприяють забезпеченню на практиці своєрідного мультиплікативного ефекту: так, доходи, отримані внаслідок вищезазначених діянь, спрямовуються на підтримку тіньової економіки та зумовлюють притягнення до себе додаткових фінансових ресурсів у наступних репродуктивних циклах [11, с. 291].

Цікавим є те, що практика приховування справжнього джерела власних доходів відома людству вже досить давно. Серед учених та науковців широко поширеною $\mathrm{E}$ думка про те, що такого роду діяння розпочалися ще понад двох тисяч років тому в Китаї, коли досить таки успішні торговці «відмивали» отримані від продажів свої прибутки, тоді як рішенням тодішньої влади було встановлено вичерпний перелік форм комерційної торгівлі, яка фактично опинилась поза законом [3, с. 97].

Наразі серед вітчизняних вчених відсутнє єдине визначення поняття «легалізація (відмивання) доходів, одержаних злочинним шляхом». Так, для прикладу, О. М. Бандурка під легалізацією (відмиванням) доходів, одержаних злочинним шляхом, пропонує розуміти: приховування істинного джерела отриманих матеріальних цінностей, перетворення незаконної готівки в іншу форму активу, приховування істинного власника незаконно набутих доходів тощо [1, с. 35]. А. М. Доля під легалізацією (відмиванням) доходів, одержаних злочинним шляхом, ро- 
зуміє як здійснення різних економічно значущих дій з одержаними внаслідок вчинення злочину грошовими коштами та іншим майном [2, с. 93].

Говорячи про законодавче закріплення поняття легалізація (відмивання) доходів, одержаних злочинним шляхом, то відповідно до положень ст. 5 Закону України «Про запобігання та протидію легалізації (відмиванню) доходів, одержаних злочинним шляхом, фінансуванню тероризму та фінансуванню розповсюдження зброї масового знищення», до легалізації (відмивання) доходів, одержаних злочинним шляхом, належать будь-які дії, пов'язані із вчиненням фінансової операції чи правочину з доходами, одержаними злочинним шляхом, а також вчиненням дій, спрямованих на приховання чи маскування незаконного походження таких доходів, чи володіння ними, прав на такі доходи, джерел їх походження, місцезнаходження, переміщення, зміну їх форми (перетворення), а так само набуттям, володінням або використанням доходів, одержаних злочинним шляхом [10].

Частиною 1 ст. 209 (Легалізація (відмивання) майна, одержаного злочинним шляхом) КК України це поняття трактується дещо по іншому, набуття, володіння, використання, розпорядження майном, щодо якого фактичні обставини свідчать про його одержання злочинним шляхом, у тому числі здійснення фінансової операції, вчинення правочину з таким майном, або переміщення, зміна форми (перетворення) такого майна, або вчинення дій, спрямованих на приховування, маскування походження такого майна або володіння ним, права на таке майно, джерела його походження, місцезнаходження, якщо ці діяння вчинені особою, яка знала або повинна була знати, що таке майно прямо чи опосередковано, повністю чи частково одержано злочинним шляхом [8].

Отже, необхідно підтримати точку зору О. М. Рєзніка та Н. М. Щербака, які доречно звертають увагу, що легалізація доходів, отриманих злочинним шляхом, за своєю природою є нічим іншим як процесом виведення в законний обіг певних грошових коштів, які були отримані внаслідок незаконної діяльності. Сам процес легалізації грошових коштів є доволі складним. Так, доходи, які були одержані злочинним шляхом, проводяться через фінансову систему з метою замаскувати їх нелегальне походження, а отже, надати їм фактичного вигляду законно отриманих коштів. Безпосереднє виведення такого роду грошових коштів здійснюеться шляхом використання незаконних фінансових операцій та фінансових інструментів, які допомагають приховати справжнє походження коштів та/або справжнього їх власника. Як правило, операції з легалізації (відмивання) коштів - це в цілому легальні фінансові операції. Разом із тим походження коштів, що в них використовуються, є злочинним [11, с. 291-292].

Сьогодні в Україні спостерігається тенденція до зростання обсягів легалізації (відмивання) доходів, одержаних злочинним шляхом, що спричиняє погіршення стану економічної безпеки національної економіки. У цьому контексті необхідно звернути увагу, що система по боротьбі з легалізацією (відмиванням) доходів, одержаних злочинним шляхом, вимагає постійного розвитку та удосконалення, пильності контролюючих органів, розроблення ефективної нормативно-правової бази, прозорості економічних процесів [7, с. 39].

Також у процесі легалізації (відмивання) доходів, одержаних злочинним шляхом, використовується широкий спектр неправомірних схем, які можливо систематизувати за наступними критеріями: 1) джерелом походження незаконних доходів; 2) видом активу, який фактично виконує роль об'єкта, за допомогою якого реалізовується процес трансформації незаконних коштів; 3) інституціями, які використовуються у процесі легалізації (відмивання) доходів, одержаних злочинним шляхом; 4) каналами реалізації, які дозволяють трансформувати такого роду кошти у прихованій формі [11, с. 292].

Незважаючи на прийняття останнім часом у багатьох країнах світу законів, що вимагають від учасників ринку активно сприяти у запобіганні та виявленні операцій, пов'язаних 3 легалізацією (відмивання) доходів, одержаних злочинним шляхом, проблему управління ризиком залучення господарюючих суб'єктів у процеси легалізації злочинних доходів не 


\section{Кримінальне право, кримінальний процес та криміналістика}

можна вирішити лише за рахунок дотримання вимог, що висуваються державою. Заходи, спрямовані на управління цим ризиком, повинні вживатися самими учасниками ринку та громадянами, і основним мотивом, що спонукає їх свідомо відмовлятися від проведення операцій з легалізацією (відмиванням) доходів, одержаних злочинним шляхом та вживати заходів щодо недопущення використання своїх рахунків у подібних цілях, є мінімізація власних ризиків [9, с. 66].

Досліджуючи питання, що пов'язані 3 впливом легалізації (відмивання) доходів, одержаних злочинним шляхом, на економічну сферу України в сучасних умовах необхідно виокремити такі найпоширеніші джерела походження доходів, одержаних злочинним шляхом:

1. Державний сектор економіки. Головною проблемою виникнення цього джерела легалізації, у першу чергу, є те, що посадові особи державних підприємств не зацікавлені у покращенні рівня їх функціонування, а тому спрямовують свої дії на залучення додаткових доходів за рахунок власної незаконної діяльності, оскільки переконані, що тривалість їх управління прямо пов'язана 3 політичною ситуацією, яка в Україні швидко змінюеться. Типовими прикладами в цьому випадку є маніпуляції з тендерними закупівлями, фінансові махінації з перерахуванням коштів державних підприємств за послуги, які фактично не були їм надані тощо.

2. Шахрайство. Найпоширенішим прикладом у цьому випадку є розкрадання коштів банківських установ. Такий вид легалізації передбачає використання фінансових установ у злочинних цілях, що обумовлено відсутністю у переважної більшості банків внутрішнього фінансового моніторингу 3 метою попередження та протидії злочинам, пов'язаних 3 легалізацією (відмиванням) доходів, одержаних злочинним шляхом.

3. Корупиійні дї чиновників. Правова природа виникнення цього джерела полягає у наділенні законодавцем посадових осіб органів влади низкою значних повноважень, які досить часто застосовуються ними 3 метою власного збагачення.

4. Кіберзлочини. Стрімкий розвиток інформаційних технологій у фінансовій сис- темі держави призвів до виникнення таких схем легалізації, як: фінансові операції 3 дистанційного отримання доступу до систем банківського обслуговування, махінації 3 платіжними картками 3 метою отримання персональних даних осіб. У подальшому такого роду інформація та доходи конвертуються у валюту, криптовалюту чи то в товари через різноманітні Інтернет-магазини [6].

Говорячи про активи, які можуть використовуватись у ході легалізації (відмивання) доходів, одержаних злочинним шляхом, то ними можуть бути:

1. Цінні папери. Поширення схем легалізації з використанням цінних паперів полягає у самій їх специфіці, тобто властивості деяких 3 них дозволяють маскувати справжні фінансові операції, які є частиною тієї чи іншої схеми.

2. Земля. Вдалим прикладом схем з безпосереднім використанням цього виду активу є скуповування землі резидентом України за позикові кошти нерезидента. Після чого нерезидент здійснює відчуження всіх активів резидента-боржника на власну користь за рахунок погашення позики.

3. Нерухоме майно. Найбільш поширеним способом легалізації доходів у цьому випадку є використання соціально-незахищених верств населення, шляхом відібрання в них майна внаслідок здійснення фальсифікації документів (права власності, про смерть, заповіт тощо) 3 подальшим продажем такого майна третім особам.

4. Високоліквідні активи, такі, як золото, діаманти, різноманітні ювелірні вироби тощо. Походження схем із використанням високоліквідних активів в Україні зумовлюється розвиненою контрабандою, а також високим рівнем корупції в органах прикордонного та митного контролю. Застосування цих схем легалізації надає можливість особам значно завищити ціну таких активів та використовувати їх як платіжний засіб у багатьох країнах зі слабким контролем за обігом такого роду предметів.

Щодо каналів реалізації схем легалізації (відмивання) доходів, одержаних злочинним шляхом, то найпоширенішими 3 них 6 :

1. Банківський переказ. Фактично визнається основою схем для відмивання неле- 
гальних доходів, оскільки в процесі його використання в осіб не виникає майже ніяких труднощів перемістити кошти до будь-якої людини в будь-якій країні.

2. Конвертаиійні центри - це найчастіше фіктивні підприємства або ж підприємства чи установи, керівники яких також залучені в процес відмивання доходів, одержаних злочинним шляхом. У переважній більшості випадків такі підприємства реалізують схеми легалізації коштів під виглядом надання фінансової чи благодійної допомоги.

3. Використання платіжних систем. Вдалим прикладом використання цього каналу є перерахунок, як правило, громадянам інших держав грошових коштів із карткових рахунків, використовуючи платіжні системи. Такого роду фінансові операції відбуваються, перш за все, внаслідок несанкціонованого доступу до відповідних рахунків громадян.

4. Контрабанда. 3 метою приховання або легалізації доходів, одержаних злочинним шляхом, у процесі перетину державного кордону грошових коштів чи високоліквідних активів часто порушуються правила митного контролю, що, зокрема, обумовлено неефективністю роботи державних органів нашої країни, а також незахищеністю частини українського кордону [11, с. 292].

\section{Висновки}

Отже, враховуючи викладене вище, необхідно зазначити, що в основі державної політики у сфері легалізації (відмивання) доходів, одержаних злочинним шляхом декларуються міжнародно-правові зобов'язання України та інтереси захисту від протиправних посягань на функціонування національної економіки. Притримуючись міжнародних стандартів, Україна повинна враховувати особливості їх реалізації з урахуванням національної правової системи та конкретних соціально-економічних умов, які існують у суспільстві. Зазначене визначає вектор розв'язання проблеми, яка пов'язана 3 пошуком балансу між дотриманням міжнародних стандартів та врахуванням національних інтересів.

Аегалізація (відмивання) доходів, одержаних злочинним шляхом належить до суспільно небезпечних діянь, що посягають на громадські інтереси, потерпілими від яких є суспільство та держава. У зв'язку з цим, реалізація кримінальної відповідальності залежить від компетентності правоохоронних органів, а також інших уповноважених органів держави та адекватності оцінки (кваліфікації) посягань на економічні інтереси держави.

\section{Мітература}

1. Бандурка А. М. Украина против «грязных» денег: науч.-практ. пособ. Национальный университет внутренних дел. Харьков: Основа, 2003. 224 с.

2. Доля Л. М. Небезпека легалізації (відмивання) грошових коштів та іншого майна, одержаних злочинним шляхом. Право Украӥни. 2002. № 2. С. 89-93.

3. Дудоров О. О., Тертиченко Т. М. Протидія відмиванню «брудного» майна: європейські стандарти та Кримінальний кодекс України: монографія. Київ: Ваіте, 2015. 392 с.

4. Захаров В. П. Легалізація (відмивання) доходів, одержаних злочинним шляхом: теоретико-правовий аспект. Вісник Національного університету «Львівська політехніка». Юридичні науки. 2014. № 801. C. $180-186$.

5. Інформування про результати роботи Державної служби фінансового моніторингу України за 9 місяців 2021 року. URL: https://fiu.gov.ua/pages/dijalnist/funkcional/ news/Informuvannya-pro-rezultati-robotiderzhfinmonitoringu-za-9-misyacziv-2021roku.html (дата звернення: 10.12.2021р.).

6. Кіберзлочинність та відмивання коштів: Департамент фінансових розслідувань. Державна служба фінансового моніторингу України. URL : http://www.sdfm. gov.ua/content/file/Site_docs/2013/20131230/ tipolog2013. pdf (дата звернення: 11.12.2021).

7. Коваль М. Аегалізація грошей, отриманих злочинним шляхом як загроза економічній безпеці України. Формування сучасной наукової думки: матер. міжнарод. наук. конф. (Кропивницький, 31 січ. 2020 р.). С. 37-40.

8. Кримінальний кодекс України: Закон України від 05.04.2001 р. № 2341-III. Відомості Верховної Ради Украйни. 2001. № 2526. Ст. 131. 


\section{Кримінальне право, кримінальний процес та криміналістика}

у статті досліджено вплив легалізачї (відмивання) доходів, одержаних злочинним иляхом, на економічну сферу Украӥни в сучасних умовах. У ході дослідження з'ясовано, що належне забезпечення начіональних економічних інтересів вимагає формування $i$ реалізаиіӥ стратегічного курсу у сбері економічної безпеки. Автором звернута увага на те, що протидія легалізаиї (відмивання) доходів, одержаних злочинним шляхом, потребує усвідомлення природи та чинників поширення ивого суспільнонебезпечного явища съогодення, а також відповідного правового забезпечення, узгоденого з міжнародними стандартами та практиками.

Наголошено, що убезпечення економічноі системи на всіх рівнях управління є важливим завданням для переважної більшості краін світу, оскільки вирішити економічні проблеми иілої держави чи регіону неможливо без належного забезпечення їм економічної безпеки та стабільного розвитку.

У роботі зазначено, що съогодні легалізачія (відмивання) доходів, одержаних злочинним шляхом, $є$ одним з найприбутковіших видів незаконного підприємництва у всъому світі. У ході дослідження наводяться дані Державної служби ббінансового моніторингу України (як підрозділу бонансової розвідки) у частині здійснення заходів з протидї легалізаий (відмиванню) доходів, одержаних злочинним шляхом, бінансуванню тероризму, сепаратизму, a також виокремлюються найпоширеніші джерела походження доходів, одержаних злочинним шляхом.

Ключові слова: легалізачія (відмивання) доходів, одержаних злочинним шляхом; економічна сфера; фінансова безпека; фінансова система; національна безпека; високоліквідні активи.

9. Магомедов ШІ. М., Каратаев М. В. Методические материалы. «Противодействие легализации (отмыванию) доходов, полученных преступным путем»: метод. рекоменд. Москва. РАДУГА. 70 с.

10. Про запобігання та протидію легалізації (відмиванню) доходів, одержаних злочинним шляхом, фінансуванню теро-

\section{SUMMARY}

The article examines the impact of legalization (laundering) of proceeds from crime on the economic sphere of Ukraine in modern conditions. The study found that the proper provision of national economic interests requires the formation and implementation of a strategic course in the field of economic security. The author draws attention to the fact that combating the legalization (laundering) of proceeds from crime requires awareness of the nature and factors of the spread of this socially dangerous phenomenon today, as well as appropriate legal support in line with international standards and practices.

It is emphasized that securing the economic system at all levels of government is an important task for the vast majority of countries. Because it is impossible to solve the economic problems of the whole country or region without proper provision of economic security and stable development.

The paper notes that today the legalization (laundering) of proceeds from crime is one of the most lucrative types of illegal business in the world. The study presents data from the State Financial Monitoring Service of Ukraine (as a financial intelligence unit) in terms of implementing measures to combat money laundering, terrorist financing, separatism, and identifies the most common sources of proceeds of crime.

Keywords: legalization (laundering) of proceeds from crime; economic sphere; financial security; financial system; National security; highly liquid assets.

ризму та фінансуванню розповсюдження зброї масового знищення: Закон України від 06.12.2019 p. № 361-IX. URL: https://zakon. rada.gov.ua/laws/ show/361-20/ed20200816 (дата звернення: 12.12.2021).

11. Рєзнік О. М., Щербак Н. М. Вплив легалізації доходів, одержаних злочинним шляхом, на фінансову систему України. Юридичний науковий електронний журнал. 2021. № 3. С. 290-293.

12. Стратегія економічної безпеки України на період до 2025 року: затв. Указом Президента України від11.08.2021 p. № 347/2021. URL: https://zakon.rada.gov.ua/ laws/show/347/2021\#n11 (дата звернення: 10.12.2021). 